\title{
Morphometric Study of Schistosoma mansoni Adult Worms Recovered from Undernourished Infected Mice
}

\author{
Sheilla A Oliveira, Aryon A Barbosa Jr.*, Delir C Gomes**/++, José Roberto Machado- \\ Silva ${ }^{* * * /++}$, Andréia F Barros, Renata Heisler Neves***, Eridan M Coutinho/ ${ }^{+}$
}

\begin{abstract}
Laboratório de Imunopatolologia, Departamento de Imunologia, Centro de Pesquisas Aggeu Magalhães-Fiocruz, Av. Moraes Rego s/nº 50670-420 Recife, PE, Brasil *Laboratório de Histopatologia, Centro de Pesquisas Gonçalo Moniz-Fiocruz, Salvador, BA, Brasil **Laboratório de Helmintos Parasitos de Vertebrados, Departamento de Helmintologia, Instituto Oswaldo Cruz-Fiocruz, Rio de Janeiro, RJ, Brasil ***Laboratório de Helmintologia Romero Lascasas Porto, Departamento de Patologia e Laboratórios, Uerj, Rio de Janeiro, RJ, Brasil
\end{abstract}

Some unfavourable effects of malnutrition of the host on Schistosoma mansoni worm biology and structure have been reported based upon brigthfield microscopy. This paper aims to study by morphometric techniques, some morphological parameters in male and female adult worms recovered from undernourished albino mice in comparison with parasites recovered from well-fed infected mice. Undernourished animals were fed a multideficient and essentially low protein diet (RBD diet) and compared to well-fed control mice fed with the commercial diet NUVILAB. Seventy-five days post-infection with 80 cercarie (BL strain) animals were sacrificed. All adult worms were fixed in $10 \%$ formalin and stained with carmine chloride. One hundred male and 60 female specimens from each group (undernourished and control) were examined using an image system analysis Leica Quantimet 500C and the Sigma Scan Measurement System. The following morphometrical parameters were studied: body length and width, oral and ventral suckers, number and area of testicular lobes, length and width of ovary and uterine egg. For statistical analysis, the Student's t test for unpaired samples was applied. Significant differences $(p<0.05)$ were detected in body length and width, in parameters of suckers, uterine egg width, ovary length and area of testicular lobes, with lower values for specimens from undernourished mice. The nutritional status of the host has negative influence on $\mathrm{S}$. mansoni adult worms, probably through unavailability of essential nutrients to the parasites.

Key words: Schistosoma mansoni - nutritional status - adult worms - morphometric study

Morphological and morphometric studies of Schistosoma mansoni adult worms have been used not only to elucidate taxonomic questions about the main species known to infect man (Bilharz 1852, Weinland 1858, Sambon 1907, Pirajá da Silva 1908), as well as to detect differences in worms recovered from different hosts (Kastner et al. 1975, Dias \& Piedrabuena 1980, Machado-Silva et al. 1994, Neves et al. 1998) or pertaining to different strains (Magalhães \& Carvalho 1973, Paraense \& Corrêa 1981, El-Mansoury \& Bayoumi 1995, Machado-Silva et al. 1995) regarding some specific quantitative parameters.

Besides brightfield and scanning electron microscopies of adult schistosomes, recent studies with the confocal laser scanning microscopy provided a superior tool to investigate external and internal helminth morphological aspects (Lenzi et al. 1997), allowing a deeper insight on its inner organization, in both well-fed (MachadoSilva et al. 1998) and undernourished mice (Neves et al. 2001).

${ }^{+}$Corresponding author. Fax: $+55-81-3453.2449$. E-mail: ecoutinho@cpqam.fiocruz.br

${ }^{++}$Conselho Nacional de Desenvolvimento Científico e Tec ológico (CNPq) Fellowships.

Rec ived 15 April 2003

Acc pted 28 May 2003
Past literature has reported on unfavourable effects of malnutrition of the host on Schistosoma biology, such as body underdevelopment and reduction of the parasite burden when compared to control well-fed animals (De Witt 1957, Magalhães et al. 1986), but few systematic morphological and morphometric studies have been reported on Schistosoma recovered from undernourished animals (Neves et al. 2001, 2002).

This paper aims to study the most important morphological parameters in adult male and female $S$. mansoni recovered from undernourished albino mice through morphometric techniques, making a comparison with parasites recovered from well-fed infected mice. These findings may have implications regarding the intensity of infection and the natural history of schistosomiasis in deficient hosts.

\section{MATERIALS AND METHODS}

Albino Swiss Webster mice were percutaneously infected with 80 cercariae (BL strain) shed from Biomphalaria glabrata. Undernourished animals were fed a multideficient and essentially low protein diet (RBD diet) and compared to well-nourished control mice fed with the commercial diet NUVILAB (Coutinho et al. 1997). Animals were sacrificed with $6 \%$ pentobarbital $(90 \mathrm{mg} / \mathrm{kg}$ IP) and perfused according to Duvall and De Witt (1967), 75 days post-infection. All specimens were fixed in $10 \%$ formalin, stained with carmine chloride, clarified in creosote and preserved as whole-mounts (Machado-Silva et al. 1994). 
One hundred male and 60 female specimens from undernourished mice and 100 male and 100 female specimens from controls were examined using an image system analysis Leica Quantimet 500C (Leica Cambridge, Cambridge, UK) coupled to a semi-authomatic device for morphometry Sigma Scan Measurement System (Jandel Scientific, San Francisco, US).

The following parameters were studied for male worms: body length and area; distance between the anterior body extremity and the posterior end of the testes; body width in three regions (anterior, middle and posterior portions); number and area of testicular lobes; area of the oral and ventral suckers; distance between the suckers.

Female worms were studied according to the following parameters: total body length; distance from the genital pore to the end of the vitelline glands; body width in three regions (anterior, middle and posterior portions); length, width and area of ovary; length and width of uterine egg; area of the oral and ventral suckers; distance between the suckers.

For statistical analysis, the Student's t test for unpaired samples was applied. Significant differences were considered for $\mathrm{p}<0.05$. Software SPSS Version 8.0 was used for the tests.

\section{RESULTS}

Significant differences $(p<0.05)$ were detected in eight parameters in male worms and in nine characters in female worms, with lower values for specimens from undernourished mice (Tables I, II). Worms derived from undernourished mice were smaller than those from well-fed controls.

All the female parasites collected from well-fed mice showed eggs in the uterus while the presence of intrauterine eggs was detected in only $84 \%$ of those worms recovered from undernourished mice.

\section{DISCUSSION}

A number of issues have significantly strengthened the link between malnutrition and parasitic helminth infections other than S. mansoni (Oberhelman et al. 1998, Stephenson et al. 2000, Crompton \& Nesheim 2002, Muniz et al. 2002). All studies support the view that parasites may negatively influence the host's nutritional status, and with it, physical growth, psychomotor and educational developments are also affected (Stephenson et al. 2000). Curiously, relatively few studies have examined the effects of malnutrition on the parasites (Boes \& Helwigh 2000). Otherwise, some progress has been made on the $S$. mansoni-malnutrition relationships in the murine model. In this context, it has been established that malnutrition hampers the outcome of the infection as well as adult worms growth (Ferreira \& Coutinho 1999). Although the effects of host's nutrition on the parasite worms are not completely understood (Mendonça et al. 2000), it is likely that the worm life span can be shortened under food restriction of the host.

Various hormones of vertebrate hosts have been implicated in the stimulation or induction of growth or sexual reproduction of their parasites (Lawrence 1991). It is also known that in IL-7-deficient mice, S. mansoni female worms show an altered fecundity, leading to decreased numbers of eggs trapped in the tissues and to an amilioration of the pathology in the infected host. Therefore, changes in the host metabolism occurring in malnutrition may impair their biological behavior (Ferreira \& Coutinho 1999).

Although it had been noticed since De Witt (1957) and Magalhães et al. (1986) that schistosomes raised in underfed mice were smaller and usually did not reach sexual maturity, detailed morphometric data on adult worms are scarce. Measurement of worm lengths and evaluating

TABLE I

Morphological parameters for male Schistosoma mansoni worms recovered from well fed and undernourished mice $(\mathrm{n}=100)$

\begin{tabular}{|c|c|c|c|}
\hline \multirow[b]{2}{*}{ Male worm characters } & \multicolumn{3}{|c|}{ Mice } \\
\hline & Well fed $\mathrm{X} \pm \mathrm{DP}$ & Undernourished $\mathrm{X} \pm \mathrm{DP}$ & P value \\
\hline $\begin{array}{l}\text { Body } \\
\quad \text { total length }(\mathrm{mm})\end{array}$ & $9 \pm 1$ & $7 \pm 1$ & $0.0001^{a}$ \\
\hline $\begin{array}{l}\text { Distance } \\
\text { between anterior extremity and the end of } \\
\text { testicular lobes }(\mu \mathrm{m})\end{array}$ & $469 \pm 7$ & $368 \pm 13$ & $0.0001^{a}$ \\
\hline Area $\left(\mu \mathrm{m}^{2}\right)$ & $3383151 \pm 74461$ & $2674217 \pm 104934$ & $0.0001^{a}$ \\
\hline $\begin{array}{l}\text { Width } \\
\text { Anterior portion }(\mu \mathrm{m}) \\
\text { Middle portion }(\mu \mathrm{m}) \\
\text { Posterior end }(\mu \mathrm{m})\end{array}$ & $\begin{aligned} 93 & \pm 2 \\
196 & \pm 17 \\
92 & \pm 2\end{aligned}$ & $\begin{array}{r}95 \pm 3 \\
176 \pm 3 \\
110 \pm 2\end{array}$ & $\begin{array}{l}0.6185 \\
0.2537 \\
0.0001^{a}\end{array}$ \\
\hline $\begin{array}{l}\text { Suckers } \\
\text { Oral area }\left(\mu \mathrm{m}^{2}\right) \\
\text { Ventral area }\left(\mu \mathrm{m}^{2}\right) \\
\text { Distance }(\mu \mathrm{m})\end{array}$ & $\begin{aligned} 4275 & \pm 139 \\
5628 & \pm 205 \\
127 & \pm 3\end{aligned}$ & $\begin{aligned} 3434 & \pm 207 \\
4078 & \pm 243 \\
94 & \pm 5\end{aligned}$ & $\begin{array}{l}0.0009^{a} \\
0.0001^{a} \\
0.0001^{a}\end{array}$ \\
\hline $\begin{array}{l}\text { Testicular lobes } \\
\text { Number } \\
\text { Area }\left(\mu \mathrm{m}^{2}\right)\end{array}$ & $\begin{aligned} 6 & \pm 0.12 \\
2786 & \pm 81\end{aligned}$ & $\begin{aligned} 6 & \pm 0.17 \\
2366 & \pm 121\end{aligned}$ & $\begin{array}{l}0.4808 \\
0.0044^{a}\end{array}$ \\
\hline
\end{tabular}

a: statistical significance $(\mathrm{p}<0.05)$ 
TABLE II

Morphological parameters for female S. mansoni worms recovered from well fed and undernourished mice $(\mathrm{n}=60)$

\begin{tabular}{|c|c|c|c|}
\hline \multirow[b]{2}{*}{ Female worm characters } & \multicolumn{3}{|c|}{ Mice } \\
\hline & Well-nourished $\mathrm{X} \pm \mathrm{DP}$ & Undernourished $\mathrm{X} \pm \mathrm{DP}$ & $P$ value \\
\hline $\begin{array}{l}\text { Body } \\
\quad \text { total length (mm) }\end{array}$ & $10 \pm 1$ & $12 \pm 1$ & $0.0001^{a}$ \\
\hline $\begin{array}{l}\text { Distance } \\
\text { from the genital pore to the } \\
\text { end of vitelline glands (mm) }\end{array}$ & $9.22 \pm 1.27$ & $11.34 \pm 1.36$ & $0.0001^{a}$ \\
\hline $\begin{array}{l}\text { Width } \\
\text { Anterior portion }(\mu \mathrm{m}) \\
\text { Middle portion }(\mu \mathrm{m}) \\
\text { Posterior end }(\mu \mathrm{m})\end{array}$ & $\begin{array}{r}74 \pm 10 \\
192 \pm 31 \\
103 \pm 28\end{array}$ & $\begin{aligned} 79 & \pm 8 \\
174 & \pm 19 \\
113 & \pm 15\end{aligned}$ & $\begin{array}{l}0.0030^{a} \\
0.0001^{a} \\
0.0100^{a}\end{array}$ \\
\hline $\begin{array}{l}\text { Suckers } \\
\text { Oral area }\left(\mu \mathrm{m}^{2}\right) \\
\text { Ventral area }\left(\mu \mathrm{m}^{2}\right) \\
\text { Distance }(\mu \mathrm{m})\end{array}$ & $\begin{aligned} 2693 & \pm 982 \\
2718 & \pm 1033 \\
174 & \pm 55\end{aligned}$ & $\begin{aligned} 2547 & \pm 900 \\
2149 & \pm 798 \\
179 & \pm 48\end{aligned}$ & $\begin{array}{l}0.3380 \\
0.0001^{a} \\
0.5730\end{array}$ \\
\hline $\begin{array}{l}\text { Ovary } \\
\text { Length }(\mu \mathrm{m}) \\
\text { Width }(\mu \mathrm{m}) \\
\text { Area }\left(\mu \mathrm{m}^{2}\right)\end{array}$ & $\begin{aligned} 416 & \pm 86 \\
147 & \pm 32 \\
57048 & \pm 11765\end{aligned}$ & $\begin{aligned} 458 & \pm 48 \\
139 & \pm 23 \\
47779 & \pm 9317\end{aligned}$ & $\begin{array}{l}0.0010^{a} \\
0.0570^{a} \\
0.0001^{a}\end{array}$ \\
\hline $\begin{array}{l}\text { Uterine egg } \\
\text { Length }(\mu \mathrm{m}) \\
\text { Width }(\mu \mathrm{m})\end{array}$ & $\begin{aligned} 100 & \pm 13 \\
46 & \pm 9\end{aligned}$ & $\begin{aligned} 100 & \pm 10 \\
42 & \pm 9\end{aligned}$ & $\begin{array}{l}0.4480 \\
0.0080^{a}\end{array}$ \\
\hline
\end{tabular}

$a$ : statistical significance $(\mathrm{p}<0.05)$

gross anatomical changes in the genital system of female worms are recognized as useful methods in detecting effects of dietary deficiencies, at least at the acute phase (first ten weeks of infection) of experimental schistosomiasis mansoni (Akpom 1978).

In this experiment, we studied several linear and area measurements aiming to settle how undernourishment can affect the phenotypic characteristics of the adult worms. In fact, significant differences were detected in both male and female schistosome worms, when well-fed and undernourished mice were compared. Our results further support previous experimental studies showing that protein deficient diets have a negative influence inducing stunted male worms (De Witt 1957, Magalhães et al. 1986). Moreover, we have confirmed that worms from undernourished mice undergo morphometric alterations in their reproductive system (Neves et al. 2001, 2002). Nevertheless, no significant difference was demonstrated regarding the number of testicular lobes. This result is not in line with previous experimental studies that showed higher number of testes in worms recovered from mice fed a low protein diet (Magalhães et al. 1986).

In this experiment, female worms recovered from undernourished mice showed an altered oviposition, intrauterine $S$. mansoni eggs being rarely visualized. In effect, while well-nourished mice had at least one intra-uterine egg per female worm, this finding occurred only in $84 \%$ of the undernourished animals. Moreover, undernourished females presented significant morphometric differences regarding ovary area and width of the intra-uterine egg. Previous experimental studies showed that females from single-sex infection have a poorly developed ovary and vitteline glands, while other parts of the reproductive system develop normally (Erasmus 1973). Probably, egg maturation is only delayed in schistosomes recovered from malnourished hosts, since altered eggs were not seen by confocal laser scanning microscopy (Neves et al. 2001). Impairment of egg maturation also occurs in metabolic diseases such as chemically-induced diabetes mellitus of mice, leading to a lower faecal egg excretion (Hulstijn et al. 2001).

The physiological relationships between $S$. mansoni and its host are complex and the details of several biochemical processes should still be determined (Neves et al. 2001). It is well established that female schistosomes are metabolically more active than males (Tempone et al. 2002) to support oogenesis (Oliveira et al. 2000).

Schistosome live paired within nutrient-rich mesenteric veins and it is likely that this parasitic flatworm has adapted to this special biochemical environment (Badr et al. 1999). The portal residence would be ideal for adult worms exploitation of host's nutrients, as blood from the small intestine environment travels to the liver for detoxification following digestion and absorption of food (Modha et al. 1998, Shaker et al. 1998). Nevertheless, the dietary restriction induces morphological and physiological changes in the digestive tract. The small intestinal mucosa is hypotrophic with reduced mucosal thickness, villus height and crypt depth are reduced in malnourished rodents. Specific activities of lactase, maltase, sucrase and ileal hydrolase are decreased (Firmansyah 1989, Chambon-Savanovitch et al. 1999). 
It is well documented that male worms intimately control and regulate the expression of a number of female genes (LoVerde \& Chen 1991, Skelly et al. 1998). It means that females are dependent on pairing with males in order to reach normal growth, sexual maturity, eggs production, feeding (Erasmus 1986, Basch 1990, Ribeiro-Paes \& Rodrigues 1997, Kunz 2001) and possibly haemozoin synthesis (Oliveira et al. 2000).

As these factors, in conjunction, could affect the outcome of the pathologic process (Coutinho et al. 1997), one can conclude that the nutritional status of the host has a negative influence on the morphology and biology of schistosome worms of both genders, probably due to the unavailability in the blood of deficient hosts, of some essential nutrients required for adequate parasite's growth and development. If malnourishment might induce changes on the regulation and expression of genes still remains to be elucidated.

Although adult worms undergo extensive morphological changes, it seems that this is not enough to impair their reproductive capacity. The blockade of parasites growth leading to dwarf male and female worms in IL-7 deficient mice showed that these worms are able to mate and lay eggs (Wolowczuk et al. 1999). Interestingly, experimental malnutrition induced for a long-term (since lactation to adulthood) in mice has no detrimental effect on the infection (Simões et al. 2002). Finally, it can be speculated that both host and schistosomes develop a certain degree of physiological adaptation to survive in a protein-deficient environment (Ing et al. 2000).

\section{REFERENCES}

Akpom CA 1978. The oogram as a sensitive method of assessing the effect of dietary deficiency on the parasite in experimental Schistosomiasis mansoni. Trop Geogr Med 30: 219-225.

Badr SGE, Pica-Mattocia L, Moroni R, Angelico M, Cioli D 1999. Effect of bile salts on oviposition in vitro by Schistosoma mansoni. Parasitol Res 85: 421-423.

Basch PF 1990. Why do schistosomes have separate sexes? Parasitol Today 6: 160-163.

Bilharz T 1852. Apud Machado-Silva JR, Pelajo-Machado M, Lenzi HL, Gomes DC 1998. Morphological study of adult male worms of Schistosoma mansoni Sambon, 1907 by confocal laser scanning microscopy. Mem Inst Oswaldo Cruz 93: 303-307.

Boes J, Helwigh AB 2000. Animal models of intestinal nematode infections of humans. Parasitology 121: 111.

Chambon-Savanovitch C, Felgines C, Farges MC, Pernet P, Cezard J, Raul F, Cynober L, Vasson MP 1999. Severe dietary restriction initiated in aged rats: evidence for poor adaptation in terms of protein metabolism and intestinal functions. Eur J Clin Invest 29: 504-511.

Coutinho EM, Souza MM, Silva LM, Cavalcanti CL, Araújo RE, Barbosa Jr. AA, Cheever AW, Andrade ZA 1997. Pathogenesis of schistosomal "pipestem" fibrosis: a low-protein diet inhibits the development of "pipestem"fibrosis in mice. Int J Exp Pathol 78: 337-342.

Couto JLA, Ferreira HS, Rocha DB, Duarte MEL, Assunção ML, Coutinho EM 2002. Structural changes in the jejunal mucosa of mice infected with Schistosoma mansoni, fed low or high protein diets. Rev Soc Bras Med Trop 35: 601-607.

Crompton DW, Nesheim MC 2002. Nutritional impact of intestinal helminthiasis during the human life cycle. Ann Rev
Nutr 22: 35-59.

De Witt WB 1957. Experimental schistosomiasis mansoni in mice maintained on nutritionally deficient diet. II. Survival and development of Schistosoma mansoni in mice maintained on a Torula yeast diet deficient in factor 3, vitamin $\mathrm{E}$ and cystine. J Parasitol 43: 129-135.

Dias LCS, Piedrabuena AE 1980. Morphological aspects of Schistosoma mansoni in naturally infected Holochilus brasiliensis. Trans R Soc Trop Med Hyg 74: 690.

Duvall RH, De Witt WB 1967. An improved perfusion technique for recovering adult schistosomes from laboratory animals. Am J Trop Med Hyg 16: 483-486.

El Mansoury ST, Bayoumi DM 1995. Pathologic and ultrastructure characterization of two different strains of Schistosoma mansoni. J Egypt Soc Parasitol 25: 1-10.

Erasmus DA 1973. A comparative study of the reproductive system of mature, immature and "unisexual" female Schistosoma mansoni. Parasitology 67: 165-183.

Erasmus DA 1986. Structural and metabolic changes in female Schistosoma mansoni following male stimulation. J Chem Ecol 12: 1755-1764.

Ferreira HS, Coutinho EM 1999. Should nutrition be considered as a supplementary measure in schistosomiasis control? Ann Trop Med Parasitol 93: 437-447.

Firmansyah A, Suwandito L, Penn D, Lebenthal E 1989. Biochemical and morphological changes in the digestive tract of rats after prenatal and postnatal malnutrition. Am J Clin Nutr 50: 261-268.

Hulstijn M, Oliveira RMF, Moura EG, Machado-Silva JR 2001. Lower faecal egg excretion in chemically-induced diabetic mice infected with Schistosoma mansoni due to impaired egg maturation. Mem Inst Oswaldo Cruz 96: 393-396.

Ing R, Su Z, Scott ME, Koski KG 2000. Suppressed T helper 2 immunity and prolonged survival of a nematode parasite in protein-malnourished mice. Proc Natl Acad Sci USA 97: 7078-7083.

Kastner MRQ, Kohn A, Teixeira ED, Pitanga LC 1975. Estudo morfológico do Schistosoma mansoni Sambon, 1907 encontrado na espécie humana. Rev Soc Bras Med Trop 9: 247-261.

Kunz W 2001. Schistosome male-female interaction: induction of germ-cell differentiation. Trends Parasitol 17: 227-231.

Lawrence PO 1991. Hormonal effects on insects and other endoparasites "in vitro". In Vitro Cell Dev Biol 27: 487-496.

Lenzi HL, Pelajo-Machado M, Vale BS, Machado-Silva JR, Paiva DD, Mota EM, Lenzi JA 1997. Confocal laser scanning microscopy applied to the study of parasitic and infectious agents. Cell Vision 4: 196-197.

LoVerde PT, Chen L 1991. Schistosome female reproductive development. Parasitol Today 7: 303-308.

Machado-Silva JR, Galvão C, Presgrave AO, Rey L, Gomes DC 1994. Host-induced morphological changes of Schistosoma mansoni Sambon, 1907 male worms. Mem Inst Oswaldo Cruz 89: 411-416.

Machado-Silva JR, Galvão C, Oliveira RMF, Presgrave OAF, Gomes DC 1995. Schistosoma mansoni Sambon, 1907: Comparative morphological studies of some Brazilian strains. Rev Inst Med Trop São Paulo 37: 441-443.

Machado-Silva JR, Pelajo-Machado M, Lenzi HL, Gomes DC 1998. Morphological study of adult male worms of Schistosoma mansoni Sambon, 1907 by confocal laser scanning microscopy. Mem Inst Oswaldo Cruz 93: 303-307.

Magalhães LA, Carvalho JF 1973. Estudo morfológico de Schistosoma mansoni pertencentes a linhagens de Belo Horizonte (MG) e de São José dos Campos (SP). Rev Saúde Públ S Paulo 7: 289-294.

Magalhães LA, Guaraldo AM, Zanotti-Magalhães EM, Carva- 
lho JF, Sgarbieri VC, Alcântara FG 1986. Schistosomiasis mansoni in experimentally malnourished mice. Rev Saúde Públ S Paulo 20: 362-368.

Mendonça RL, Escrivá H, Bouton D, Laudet V, Pierce RJ 2000. Hormones and nuclear receptors in schistosome development. Parasitol Today 16: 233-240.

Modha J, Redman CA, Thornhill JA, Kusel JR 1998. Schistosomes: unanswered questions on the basic biology of the host-parasite relationship. Parasitol Today 14: 396-401.

Muniz PT, Ferreira MU, Ferreira CS, Conde WL, Monteiro CA 2002. Intestinal parasitic infections in young children in São Paulo, Brazil: prevalences, temporal trends and associations with physical growth. Ann Trop Med Parasitol 96: 503-512.

Neves RH, Machado-Silva JR, Pelajo-Machado M, Oliveira AS, Coutinho EM, Lenzi HL, Gomes DC 2001. Morphological aspects of Schistosoma mansoni adult worms isolated from nourished and undernourished mice: a comparative analysis by confocal laser scanning microscopy. Mem Inst Oswaldo Cruz 96: 1013-1016.

Neves RH, Oliveira AS, Machado-Silva JR, Coutinho E, Gomes DC 2002. Phenotypic characterization of Schistosoma mansoni adult worms recovered from undernourished mice: a morphometric study focusing on the reproductive system. Rev Soc Bras Med Trop 35: 405-407.

Neves RH, Pereira MJS, Oliveira RMF, Gomes DC, MachadoSilva JR 1998. Schistosoma mansoni Sambon, 1907: morphometric differences between adult worms from sympatric rodent and human isolates. Mem Inst Oswaldo Cruz 93: 309-312.

Oberhelman RA, Guerrero ES, Fernandez ML, Silio M, Mercado D, Comiskey N, Ihenacho G, Mera R 1998. Correlations between intestinal parasitosis, physical growth, and psychomotor development among infants and children from rural Nicaragua. Am J Trop Med Hyg 58: 470-475.

Oliveira MF, d'Avila JCP, Torres CR, Oliveira PL, Tempone AJ, Rumjanek FD, Braga CMS, Silva JR, Dansa-Petretski M, Oliveira MA, Souza W, Ferreira ST 2000. Haemozoin in Schistosoma mansoni. Mol Biochem Parasitol 111: 217-221.
Paraense WL, Corrêa LR 1981. Observations on two biological races of Schistosoma mansoni. Mem Inst Oswaldo Cruz 76: 287-291.

Pirajá da Silva MA 1908. Contribuição para o estudo da schistosomiase na Bahia. Brazil Med 22: 281-283.

Ribeiro-Paes JT, Rodrigues V 1997. Sex determination and female reproductive development in the genus Schistosoma: a review. Rev Inst Med Trop São Paulo 39: 337-344.

Sambon LW 1907. Remarks on Schistosoma mansoni. Am J Trop Med Hyg 10: 303-304.

Shaker YM, Wu CH, El-Shobaki FA, Ashour E, Khattab HM, Draz HM, Kamel R, Wu GY 1998. Human portal serum stimulates cell proliferation in immature Schistosoma mansoni. Parasitology 177: 293-299.

Simões C, Neves RH, Barros LA, Brito PD, Cravo CO, Moura EG, Machado-Silva JR 2002. Parasitological characteristics of Schistosoma mansoni infection in Swiss mice with underlying malnutrition. Mem Inst Oswaldo Cruz 97: 143147.

Skelly PJ, Tielens AGM, Shoemaker CB 1998. Glucose transport and metabolism in mammalian-stage schistosomes. Parasitol Today 14: 402-406.

Stephenson LS, Latham MC, Ottesen EA 2000. Malnutrtion and parasitic helminth infections. Parasitology 121: S23S38.

Tempone AJ, Furtado DR, Gimba ERT, Oliveira FMB, Rumjanek FD 2002. Dolichol phosphate mannose synthase is differentially expressed in male and female worms of Schistosoma mansoni. Comp Biochem Physiol Part B 131: 465-474.

Weinland 1858. Apud Machado-Silva JR, Pelajo-Machado M, Lenzi HL, Gomes DC 1998. Morphological study of adult male worms of Schistosoma mansoni Sambon, 1907 by confocal laser scanning microscopy. Mem Inst Oswaldo Cruz 93: 303-307.

Wolowezuk I., Nutten S, Roye O, Delacre M, Capron M, Murray RM, Trottein F, Auriault C 1999. Infection of mice lacking Interleukin-7 (IL-7) reveals an unexpected role for IL-7 in the development of the parasite Schistosoma mansoni. Infect Immun 67: 4183-4190. 